\title{
Why, When, and How to Prevent Hepatitis B Virus Reactivation in Cancer Patients Undergoing Chemotherapy
}

\author{
Bhumsuk Keam, MD; jeong-Hoon Lee, MD, PhD ${ }^{\mathrm{a}, \mathrm{b}}$; Seock-Ah Im, MD, PhD ${ }^{\mathrm{a}, \mathrm{c}}$; and \\ Jung-Hwan Yoon, MD, PhD ${ }^{\mathrm{a}, \mathrm{b}}$; Seoul, South Korea
}

Key Words

Hepatitis B virus, reactivation, chemotherapy, cancer

\begin{abstract}
Hepatitis B virus (HBV) reactivation is a serious clinical problem in HBV carriers undergoing chemotherapy. The clinical course of HBV reactivation can be separated into 2 phases: 1) an increase in HBV replication and 2 ) hepatic injury. Patients with resolved HBV infections (negative for hepatitis B surface antigen [HBsAg], and positive for both hepatitis B core antibody [anti-HBc] and/or hepatitis $B$ surface antibody) can experience HBV reactivation, and Western guidelines recommend that not only HBsAg but also anti-HBc be screened before initiation of chemotherapy or immunosuppressive therapy. Several meta-analyses have repeatedly confirmed the prophylactic role of lamivudine in preventing HBV reactivation. In conclusion, screening for HBV is required before chemotherapy, and prophylactic antiviral therapy can reduce not only the incidence of HBV reactivation but also HBV-related morbidity and mortality. (JNCCN 2011;9:465-477)
\end{abstract}

\section{Epidemiology of Hepatitis B Virus}

Hepatitis B virus (HBV) has infected more than 2 billion people worldwide, and approximately 350 million patients worldwide have chronic HBV infection. ${ }^{1,2}$ In

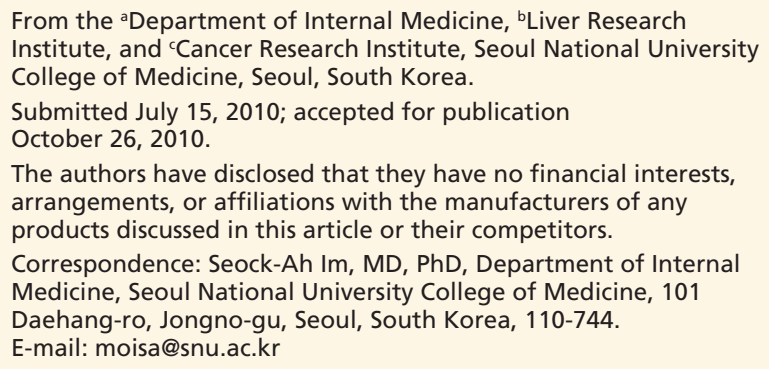

the United States, carriers of chronic hepatitis B surface antigen ( $\mathrm{HBs} \mathrm{Ag})$ continue to increase as a consequence of increasing immigration from HBV endemic areas, such as East Asia, South Asia, and Africa. The United States comprises 1.5 million of the worldwide chronic HBsAg carriers. ${ }^{3}$ In Korea, which is regarded as an endemic area of HBV infection, a nationwide survey revealed an $\mathrm{HBs}$ Ag prevalence of $5.1 \%$ in men and $4.1 \%$ in women. ${ }^{4}$

Reactivation of HBV has been well documented in infected patients receiving chemotherapy for cancer treatment..$^{5-8}$ With the increasing use of chemotherapy, reactivation of HBV has become a serious cause of morbidity and mortality. The frequency of HBV reactivation among patients with cancer who are HBsAg-positive is expected to be the same, regardless of the geographic area. ${ }^{5}$ However, the frequency of HBV reactivation in a given population differs geographically because the prevalence of HBV infection varies among different populations (from $10 \%-25 \%$ in highly endemic areas, to $<1 \%$ in other areas). ${ }^{9-11}$

Besides geographic differences, different types of cancer, different chemotherapeutic regimens, different use of antiviral agents, and the absence of well-designed prospective trials have hampered the establishment of preventive strategies for HBV reactivation. This article summarizes the current status of HBV reactivation secondary to chemotherapy, and proposes a prophylactic strategy for HBV reactivation.

\section{Diagnosis of HBV Reactivation}

Chemotherapy-induced HBV reactivation has a broad range of manifestations, ranging from asymptomatic rises in serum aminotransferase levels to fatal fulminant 
hepatitis. ${ }^{12} \mathrm{HBV}$ reactivation is characterized by elevated levels of serum HBV DNA, abnormal liver function tests, and clinical hepatitis with different degrees of severity. ${ }^{10}$ Diverse definitions for HBV reactivation have been used in previous studies, which has prevented an exact comparison of HBV reactivation. An early report described 2 types of HBV reactivation ${ }^{13}$ : 1) patients who were $\mathrm{HBs} A g$ positive experiencing an increase in serum $\mathrm{HBs} A g$ titer, and 2) patients who were HBsAg-negative/ hepatitis B surface antibody (anti-HBs)-positive with declining anti-HBs and reappearance of $\mathrm{HBs} \mathrm{Ag}$ (seroreversion). To reflect these characteristics, the most widely used definition of HBV reactivation is based on the criteria proposed by Lok et al. ${ }^{10}$ and modified by Yeo et al. ${ }^{14}$ According to this criteria, the definition of $\mathrm{HBV}$ reactivation should include 2 components: 1) the presence of hepatitis, and 2) hepatitis attributed to HBV reactivation. The definition of hepatitis is a 3 -fold or greater increase in alanine aminotransferase (ALT) that exceeds the upper limit of normal. Hepatitis attributable to HBV reactivation is defined as a 10 -fold or greater increase in HBV DNA levels compared with baseline levels, or an absolute increase in the HBV DNA level that exceeds $10^{5}$ copies $/ \mathrm{mL}$ in the absence of another systemic infection. Exact baseline evaluation and close monitoring of ALT and HBV DNA levels is mandatory for early diagnosis and prompt management of HBV reactivation. ${ }^{15}$

\section{Pathogenesis of HBV Reactivation}

Theoretically, administering any immunosuppressive therapy to patients with chronic HBV infection may allow the virus to escape immune control, leading to increased HBV replication and a marked increase in HBV antigen expression within hepatocytes. ${ }^{16}$ Approximately $50 \%$ of $\mathrm{HBV}$ reactivation occurs during the recovery phase from immunosuppression, 10 to 90 days after discontinuation of cytotoxic chemotherapy or immunosuppressive agents, ${ }^{17}$ and the other $50 \%$ occurs during immunosuppression. Hence, 2 distinct pathogenic mechanisms are believed to be associated with HBV reactivation, according to the time of onset. ${ }^{18}$ The first mechanism of reactivation during the recovery phase is an exaggerated immunologic response to $\mathrm{HBV}$-infected hepatocytes. During im- munosuppression from cytotoxic chemotherapy or immunosuppressive agents, such as glucocorticoids, viral replication increases, leading to widespread infection of hepatocytes. However, in this period, overt hepatocellular injury does not occur because cytotoxic T cells are suppressed. After immunosuppression is withdrawn, infected hepatocytes with recognizable viral antigens on their surface might be exposed and cleared by cytotoxic T cells with an exaggerated immunologic response, leading to hepatic necrosis and clinically relevant hepatitis. This mechanism is supported by the observation that HBV carriers can have an increased concentration of HBsAg and HBV DNA during immunosuppressive treatment, followed by decreased viral replication on withdrawal of immunosuppression, which is attributed to immune function. ${ }^{12,18,19}$

The second pathogenic mechanism of HBV reactivation during immunosuppression is associated with immunosuppression-induced augmentation of HBV replication that is directly toxic to host hepatocytes. Immunosuppressive agents may have a more direct stimulatory effect on viral replication. ${ }^{20}$ In vitro, glucocorticoids increase HBV DNA and RNA production by stimulating $\mathrm{HBV}$ transcription ${ }^{21,22}$ through binding to the glucocorticoid-responsive element and augmenting HBV enhancer I. In general, the first mechanism is considered to be a more important contributor for HBV reactivation.

\section{Frequency and Clinical Features of HBV Reactivation}

The frequencies of HBV reactivation are difficult to estimate from published studies because of the different definitions of HBV reactivation, heterogenous cancer types, heterogenous chemotherapy regimens, and regional differences in HBV prevalence. As the role of prophylactic lamivudine has been elucidated in patients with cancer who are $\mathrm{HBs} \mathrm{Ag}$-positive, estimating the natural frequency of HBV reactivation has become more difficult. In early prospective reports, the frequencies of HBV reactivation were reported to be $37.8 \%{ }^{23}$ in a Japanese study, and $47 \%^{10}$ and $19 \%^{14}$ in Hong Kong studies. The frequency of HBV reactivation may decrease as many guidelines ${ }^{24-27}$ have begun recommending the use of prophylactic antiviral agents before chemotherapy. 
The clinical features of HBV reactivation vary from asymptomatic hepatitis to fulminant hepatic failure leading to death. The mortality rates have been reported to range from $5 \%$ to $41 \% .{ }^{10-12,23,28}$ The clinical course of HBV reactivation can be separated into 2 phases $^{29}: 1$ ) increase in HBV replication, and 2) hepatic injury (Figure 1). In the first phase, HBV DNA or the HBsAg titer increases as viral replication occurs soon after initiating chemotherapy or immunosuppressive agents. Hepatitis $\mathrm{B}$ e antigen $(\mathrm{HBeAg})$ may reappear in patients who are initially HBeAg-negative. The second phase of reactivation usually starts when immunosuppression is withdrawn or decreased. In the second phase, serum ALT levels increase as hepatocellular damage rises, and HBV DNA may begin to decrease. Immune-mediated destruction of HBVinfected hepatocytes manifests clinically as hepatitis, hepatic failure, and even death. ${ }^{5,29,30}$ Patients with cirrhosis are more likely to develop hepatic decompensation, resulting in hepatic failure. ${ }^{5}$

\section{Risk Factors for HBV Reactivation: Patient Factors, Cancer Type, and Treatment Factors}

Identifying risk factors for HBV reactivation is clinically important because it provides guidance for prevention strategies. Several studies have reported the risk factors for HBV reactivation (Table 1). However, the risk factors have not been completely clarified because of the small sample size of each study and different clinical settings.

Early reports have failed to show that prechemotherapy viral load is a predictor for HBV reactiva-

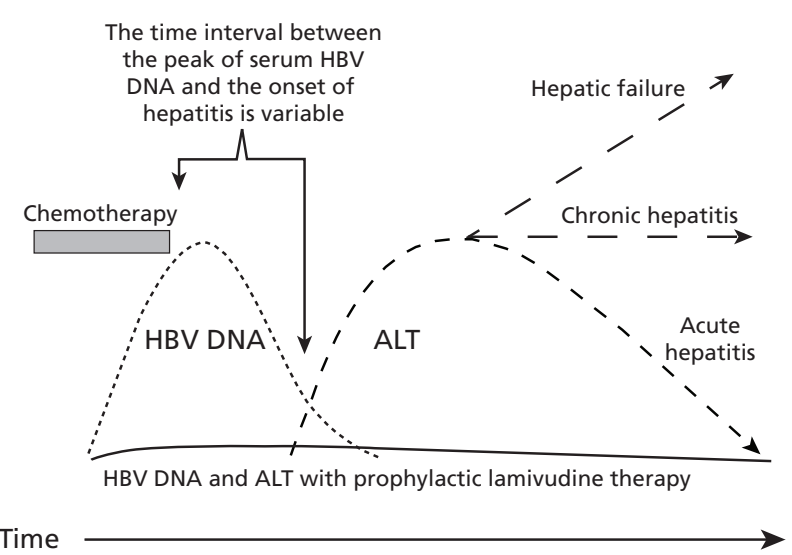

Figure 1 Clinical course of HBV reactivation. The first phase is characterized by enhanced HBV viral replication, and the second phase is characterized by an enhanced host immune response to $\mathrm{HBV}$-infected hepatocytes and hepatic injury. Abbreviations: ALT, alanine aminotransferase; HBV, hepatitis B virus.

From Lau GK. Hepatitis B reactivation after chemotherapy: two decades of clinical research. Hepatol Int 2008;2:154; with permission.

tion. ${ }^{14,15,31}$ However, with the introduction of highly sensitive assays, such as real-time polymerase chain reaction, recent studies have consistently reported that a high HBV viral load before chemotherapy is significantly associated with HBV reactivation. ${ }^{30,32,33}$ Different studies have used different assays in measuring the HBV viral load, ${ }^{5}$ and therefore a standardized method to measure HBV viral load with a variable range of detection may be needed.

Baseline prechemotherapy $\mathrm{HBeAg}$ positivity has been confirmed as a risk factor for HBV reactivation in univariate ${ }^{10,14}$ and multivariate analyses..$^{34,35}$ However, $\mathrm{HBeAg}$ positivity has not been shown to

\begin{tabular}{|c|c|c|c|c|}
\hline Reference & Cancer & $\begin{array}{l}\text { No. of HBsAg } \\
\text { Carrier Studies }\end{array}$ & $\begin{array}{l}\text { Rate of HBV } \\
\text { Reactivation }\end{array}$ & Risk Factors \\
\hline Lau et al. ${ }^{30}$ & Lymphoma & 23 & $45 \%$ & Baseline high HBV DNA level \\
\hline Nagamatsu et al. ${ }^{35}$ & $\mathrm{HCC}$ & 33 & $24 \%$ & HBeAg positivity \\
\hline Yeo et al. ${ }^{28}$ & $\mathrm{HCC}$ & 102 & $36 \%$ & Baseline high ALT level \\
\hline Yeo et al. ${ }^{33}$ & Various & 138 & $26 \%$ & $\begin{array}{l}\text { Lymphoma or breast cancer } \\
\text { Use of steroid } \\
\text { Baseline high HBV DNA level }\end{array}$ \\
\hline Hui et al. ${ }^{39}$ & Lymphoma & 22 & $41 \%$ & High intrahepatic CCC DNA level \\
\hline Jang et al. ${ }^{31}$ & $\mathrm{HCC}$ & 146 & $22 \%$ & HBeAg positivity \\
\hline
\end{tabular}

Abbreviations: ALT, alanine aminotransferase; CCC DNA, covalently closed circular DNA; HBeAg, hepatitis B e antigen; HBsAg, hepatitis B surface antigen; HBV, hepatitis B virus; HCC, hepatocellular carcinoma. 
be a risk factor in other studies, ${ }^{36,37}$ but instead may be related to the presence of precore/core promoter HBV mutants. ${ }^{38}$ One study showed that intrahepatic, covalently closed circular (CCC) DNA, which is a key intermediate in HBV replication, was associated with HBV reactivation. ${ }^{39}$ The overall accuracy of intrahepatic CCC DNA in predicting HBV reactivation was $88.9 \%$, with a sensitivity of $77.8 \%$ and a specificity of $100 \%$. However, quantification of CCC DNA requires a liver biopsy, which has inherent sampling error, and measuring the CCC DNA has limitations in its clinical applicability, especially for patients with coagulopathies. Many studies have been conducted recently to identify a validating marker to replace CCC DNA, such as the quantification of serum $\mathrm{HBsAg}{ }^{40}$

Apart from viral factors, the rate of HBV reactivation depends on the type of malignancy and the chemotherapeutic agents used. The 2 most common clinical settings in which HBV reactivation has been reported are during chemotherapy for lymphoma and during immunosuppressive treatment after hematopoietic stem cell transplantation (HSCT). However, HBV reactivation has also been reported in other solid tumors, including breast cancer, ${ }^{32,41,42}$ hepatocellular carcinoma (HCC), ${ }^{34,43}$ nasopharyngeal cancer, ${ }^{44}$ small cell lung cancer, ${ }^{45}$ and neuroendocrine tumors. ${ }^{45}$ Whether the relative lack of reports in other types of malignancies is the result of a lower degree of immunosuppression in other cancers or a lower incidence of other cancers in HBV endemic areas is unknown.

Anthracyclines and glucocorticoids are wellknown risk factors for HBV reactivation. Table 2 summarizes the reported chemotherapeutic agents that have been related to HBV reactivation. Notably, HBV reactivation can be caused by not only conventional cytotoxic chemotherapeutic agents but also molecular targeted agents. Rituximab, a chimeric monoclonal antibody directed against CD20 in lymphoid cells, has been used in the treatment of lymphomas, and has been associated with HBV reactivation when used as a single agent ${ }^{46-48}$ or in combination with cytotoxic chemotherapeutic agents. ${ }^{49-57} \mathrm{HBV}$ reactivation has also been reported in patients with hematologic malignancies treated with alemtuzumab, a humanized monoclonal antibody directed against CD52 in lymphoid cells. ${ }^{58,59}$ Rituximab and alemtuzumab have induced profound and durable $\mathrm{B}$ - and T-cell depletion, ${ }^{60,61}$ and $B$ cells may modulate the priming cytotoxic $T$ cell response to HBV infection. ${ }^{62}$

Three case reports have also shown imatinib mesylate, a tyrosine kinase inhibitor for bcr-abl and ckit, to be related to HBV reactivation. ${ }^{63-65}$ Sorafenib, the first agent documenting survival benefit in advanced $\mathrm{HCC},{ }^{66,67}$ has been used in the treatment of HCC, but HBV reactivation has not been reported in studies using sorafenib in patients with HCC. ${ }^{66-69}$ To the authors' best knowledge, HBV reactivation has not been reported in patients treated with tyrosine kinase inhibitors other than imatinib. HBV reactivation in patients with nonhematologic malignancies treated with commonly used molecular targeted agents, including gefitinib, erlotinib, sunitinib, trastuzumab, bevacizumab, and cetuximab, has not yet been elucidated. The mammalian target of rapamycin (mTOR) inhibitors, such as FK506, are already used to treat transplant rejection, and are beginning to be used as chemotherapeutic agents. Among the mTOR inhibitors, RAD001 (everolimus) has been reported to be associated with HBV reactivation. ${ }^{70}$ Further data are needed to identify the characteristics of HBV reactivation in patients treated with molecular targeted agents and to develop a prophylactic strategy.

\section{HBV Reactivation in Patients Who Are HBsAg-Negative}

Patients with resolved HBV infections (HBsAgnegative, and positive for hepatitis $\mathrm{B}$ core antibody [anti-HBc] and/or anti-HBs) can experience HBV reactivation, ${ }^{10,13,71-75}$ but this occurs less commonly than in patients who are HBsAg-positive. However, with the recent increased use of rituximab, reports of HBV reactivation after treatment with this agent in patients with resolved HBV infections have also increased. ${ }^{46-51,54-56,76}$ Based on case series, nearly $20 \%$ of patients died of hepatic failure. ${ }^{50} \mathrm{HBV}$ reactivation has also been associated with HSCT in patients with hematologic malignancies with resolved HBV infections. ${ }^{77-79}$ In endemic areas, such as the Asian-Pacific region, vertical or perinatal transmission is associated with a higher rate of progression to chronic hepatitis $\mathrm{B}(90 \%)^{80,81}$ and is the predominant form of HBV infection; a relatively lower portion of patients have resolved HBV infections. However, attention should be 


\begin{tabular}{|c|c|c|}
\hline & Agents & References \\
\hline \multirow[t]{3}{*}{ Corticosteroid } & Prednisolone & $12-14,19,39,52,54-57,97-104$ \\
\hline & Dexamethasone & $12,55,99,101-103$ \\
\hline & Methylprednisolone & 12,105 \\
\hline \multirow[t]{4}{*}{ Anthracycline } & Doxorubicin & $14,28,32,39,52,54,56,57,97-103,106$ \\
\hline & Epirubicin & $14,32,100,107$ \\
\hline & Daunorubicin & $13,102,105$ \\
\hline & Idarubicin & 98 \\
\hline \multirow[t]{3}{*}{ Antitumor metabolite } & 5-Fluorouracil & $14,28,32,99$ \\
\hline & Methotrexate & $13,14,39,97,99,101,102,104$ \\
\hline & Cytarabine & $13,49,98,101,104,105$ \\
\hline \multirow[t]{5}{*}{ Alkylating agents } & Cyclophosphamide & $13,14,19,32,39,52,54,56,57,97-104,106$ \\
\hline & Chlorambucil & 101,104 \\
\hline & Ifosfamide & 39 \\
\hline & Gemcitabine & $14,99,108,109$ \\
\hline & Mercaptopurine & 104,105 \\
\hline \multirow[t]{2}{*}{ Vinca alkaloid } & Vincristine & $13,14,19,39,52,54,56,57,97-104$ \\
\hline & Vinblastine & $14,39,97,105$ \\
\hline \multirow[t]{2}{*}{ Taxane } & Paclitaxel & 14 \\
\hline & Docetaxel & $14,32,106,107$ \\
\hline \multirow[t]{2}{*}{ Platinum } & Cisplatin & $19,28,99,101,106$ \\
\hline & Carboplatin & 14 \\
\hline \multirow[t]{3}{*}{ Antitumor antibiotics } & Mitomycin-C & 14,32 \\
\hline & Bleomycin & $19,39,97,101-103$ \\
\hline & Actinomycin D & 19 \\
\hline \multirow[t]{5}{*}{ Other cytotoxic agents } & Etoposide & $14,39,55,101,108$ \\
\hline & Procarbazine & $13,39,97,99$ \\
\hline & Dacarbazine & 97 \\
\hline & Lomustine & 99 \\
\hline & Fludarabine & 37 \\
\hline \multirow[t]{2}{*}{ Monoclonal antibodies } & Rituximab & $46-57$ \\
\hline & Alemtuzumab & 58,59 \\
\hline Tyrosine kinase inhibitors & Imatinib & $63-65$ \\
\hline \multirow[t]{2}{*}{ Immune modulators } & Thalidomide & 110 \\
\hline & Interferon & $28,49,111$ \\
\hline mTOR inhibitor & Everolimus & 70 \\
\hline
\end{tabular}

Data from Yeo W, Johnson PJ. Diagnosis, prevention and management of hepatitis B virus reactivation during anticancer therapy. Hepatology 2006;43:214.

given to patients with resolved HBV infections, especially those undergoing rituximab treatment or HSCT.

The European and United States guidelines for the management of chronic hepatitis $B$ recommend that not only $\mathrm{HBs} \mathrm{Ag}$ but also anti-HBc antibodies be screened before initiation of chemotherapy or immunosuppressive therapy. ${ }^{24,27}$ However, the Korean guidelines do not recommend routine screening for anti-HBc antibodies ${ }^{25}$ because most HBV infections result from vertical transmission in Korea. ${ }^{81}$ The Eu- 
ropean guidelines ${ }^{24}$ recommend that patients who are HBsAg-negative with positive anti-HBc and undetectable HBV DNA in the serum who undergo chemotherapy and/or immunosuppression be monitored carefully with ALT and HBV DNA testing and treated with antiviral therapy on confirmation of HBV reactivation before ALT elevation. ${ }^{24}$ The United States guidelines do not recommend routine prophylaxis for patients with resolved HBV because not enough information is available on this issue. ${ }^{27}$ The optimal approach to managing patients with resolved HBV infection must be elucidated through future research in terms of clinical benefit and cost-effectiveness. Comparison of the HBV reactivation rates between the patients who are $\mathrm{HBs} \mathrm{Ag}$-positive and resolved HBV infections is also warranted, because this is likely to have significant implications in the United States.

\section{Effect of Prophylactic Antiviral Therapy}

Many studies have shown the effectiveness of prophylactic antiviral therapy in reducing the incidence of HBV reactivation. Table 3 summarizes the current studies that have compared patients who did and did not receive prophylactic lamivudine. Several metaanalyses have repeatedly confirmed the prophylactic role of lamivudine. ${ }^{6,7,82,83}$ Loomba et al. ${ }^{6}$ analyzed 14 studies and reported the results of a meta-analysis, concluding that preventive therapy with lamivudine for patients who are HBsAg-positive and are undergoing chemotherapy may reduce the risk of HBV reactivation and $\mathrm{HBV}$-associated morbidity and mortality. With preventive lamivudine, the relative risk for HBV reactivation ranges from 0.00 to 0.21 , favoring prophylactic lamivudine.

Kohrt et al. ${ }^{7}$ and Katz et al. ${ }^{82}$ also reported similar results of meta-analyses. Although these meta-analyses were conducted using many retrospective studies, the analyzed studies were consistently in favor of prophylactic lamivudine. As a result, the consensus is emerging that prophylaxis with antiviral agents is essential for patients who are HBsAg-positive undergoing chemotherapy.

Recently, the authors retrospectively reviewed the medical records of 3530 patients with stages I through III breast cancer, and examined the efficacy of prophylactic lamivudine compared with historical controls. Among the 3530 patients, 171 (4.8\%) were $\mathrm{HBs} A g$-positive and from the authors' insti- tute, which was located in a HBV endemic area. Of the 171 patients, 70 patients received lamivudine prophylaxis and 101 patients did not. Hepatotoxicities occurred more frequently in the nonprophylactic group (2.9\% vs. $12.9 ; P=.027)$, as did HBV reactivation $(6.9 \%$ vs. $1.4 \% ; P=.143$; unpublished data).

\section{How to Use Prophylactic Antiviral Therapy: Optimal Duration and Drug}

Because the main mechanism of nucleos(t)ide analogues in inhibiting viral replication is direct suppression of HBV DNA polymerase activity, antiviral potency has been little affected by host immune status. Data are still insufficient on the optimal duration of prophylactic antiviral therapy. Premature withdrawal of lamivudine could lead to a rapid rebound of viral replication, resulting in HBV-related mortality. ${ }^{84}$ However, prolonged use of lamivudine is associated with an increasing likelihood of developing lamivudine-resistant HBV variants with YMDD mutants ${ }^{85,86}$ (from $24 \%$ at 1 year to $38 \%$ at 2 years, $50 \%$ at 3 years, and $67 \%$ at 4 years). ${ }^{87,88}$ Several patients who developed lamivudine-resistant mutations, such as a YMDD mutant during lamivudine prophylaxis, have been reported. ${ }^{89-92}$ Compared with patients with chronic hepatitis $B$, a similar rate of developing genotypic YMDD mutants was observed in patients with lymphoma. ${ }^{93}$

Hence, the current guidelines recommend discontinuing prophylactic lamivudine as soon as possible after restoration of host immune status, and setting a limit to the duration of lamivudine therapy. However, many guidelines differ in the duration of treatment, from at least 3 to 12 months after completion of chemotherapy. Hui et al. ${ }^{94}$ studied the occurrence of HBV reactivation after prophylactic lamivudine, and found that $23.9 \%$ of patients (11/46) receiving prophylactic lamivudine 3 months after completion of chemotherapy experienced HBV reactivation, and that high baseline HBV DNA (> $10^{4}$ copies $/ \mathrm{mL}$ ) and $\mathrm{HBeAg}$ were significantly associated with $\mathrm{HBV}$ reactivation. Based on this study, patients with high baseline HBV DNA or HBeAg should be followed up closely for a longer period of lamivudine prophylaxis with the same end point of immunocompetent patients, such as HBeAg seroconversion. In the authors' clinical practice, prophylactic lamivudine is started at least 1 week before chemotherapy, and continued for 


\section{Table 3 Current Studies on the Role of Prophylactic Lamivudine}

\begin{tabular}{|c|c|c|c|c|c|}
\hline Studies & Cancer & Country & Prophylaxis Schedule & $\begin{array}{l}\text { Incidence of HBV } \\
\text { Reactivation } \\
\text { Lamivudine vs. } \\
\text { No Lamivudine }\end{array}$ & Comments \\
\hline \multicolumn{6}{|c|}{ Retrospective Comparative Case Series } \\
\hline Lim et al. ${ }^{99}$ & Various & Singapore & $\begin{array}{l}\text { Before start of chemotherapy } \\
\text { Until completion of } \\
\text { chemotherapy }\end{array}$ & $\begin{array}{l}0.0 \%(0 / 16) \text { vs. } \\
36.8 \%(7 / 19)\end{array}$ & Dose: $100-300 \mathrm{mg}$ \\
\hline \multirow[t]{2}{*}{$\begin{array}{l}\text { Persico } \\
\text { et al. }{ }^{112}\end{array}$} & Lymphoma & Italy & $\begin{array}{l}\text { During and after } \\
\text { chemotherapy }\end{array}$ & $\begin{array}{l}0.0 \%(0 / 3) \text { vs. } \\
57.1 \%(12 / 21)\end{array}$ & \\
\hline & & & $\begin{array}{l}2 \text { mo after completion of } \\
\text { chemotherapy }\end{array}$ & & \\
\hline Lee et al. ${ }^{113}$ & Lymphoma & Korea & Details not reported & $\begin{array}{l}9.1 \%(1 / 11) \text { vs. } \\
85.0 \%(17 / 20)\end{array}$ & \\
\hline $\begin{array}{l}\text { Leaw et } \\
\text { al. }{ }^{114}\end{array}$ & Lymphoma & Taiwan & $\begin{array}{l}\text { Start of chemotherapy } \\
1 \text { mo after completion of } \\
\text { chemotherapy }\end{array}$ & $\begin{array}{l}0.0 \%(0 / 11) \text { vs. } \\
32.1 \%(17 / 53)\end{array}$ & \\
\hline $\begin{array}{l}\text { Nagamatsu } \\
\text { et al. }{ }^{43}\end{array}$ & $\mathrm{HCC}$ & Japan & $\begin{array}{l}4 \text { wk before chemotherapy } \\
\text { Until completion of } \\
\text { chemotherapy }\end{array}$ & $\begin{array}{l}0.0 \%(0 / 8) \text { vs. } \\
66.7 \%(6 / 9)\end{array}$ & $\begin{array}{l}\text { TACE, all patients } \\
\text { were } \mathrm{HBeAg} \text { - } \\
\text { positive }\end{array}$ \\
\hline $\begin{array}{l}\text { Ozguroglu } \\
\text { et al. }{ }^{115}\end{array}$ & Lymphoma & Turkey & Details not reported & $\begin{array}{l}0.0 \%(0 / 4) \text { vs. } \\
62.5 \%(5 / 8)\end{array}$ & \\
\hline \multicolumn{6}{|c|}{ Prospective Cohort Studies With Historical Control Groups } \\
\hline Dai et al. ${ }^{106}$ & Breast & Taiwan & $\begin{array}{l}\text { Start of chemotherapy } \\
1 \text { mo after completion of } \\
\text { chemotherapy }\end{array}$ & $\begin{array}{l}0.0 \%(0 / 11) \text { vs. } \\
55.6 \%(5 / 9)\end{array}$ & \\
\hline Yeo et al. ${ }^{116}$ & Various & Hong Kong & $\begin{array}{l}1 \text { wk before chemotherapy } \\
2 \text { mo after completion of } \\
\text { chemotherapy }\end{array}$ & $\begin{array}{l}4.6 \%(3 / 65) \text { vs. } \\
24.4 \%(47 / 193)\end{array}$ & \\
\hline Yeo et al. ${ }^{42}$ & Breast & Hong Kong & $\begin{array}{l}1 \text { wk before chemotherapy } \\
2 \text { mo after completion of } \\
\text { chemotherapy }\end{array}$ & $\begin{array}{l}6.5 \%(2 / 31) \text { vs. } \\
31.1 \%(19 / 61)\end{array}$ & \\
\hline Yeo et al. ${ }^{44}$ & Nasopharyngeal & Hong Kong & $\begin{array}{l}1 \text { wk before chemotherapy } \\
2 \text { mo after completion of } \\
\text { chemotherapy }\end{array}$ & $\begin{array}{l}0.0 \%(0 / 16) \text { vs. } \\
28.6 \%(6 / 21)\end{array}$ & \\
\hline \multicolumn{6}{|c|}{ Prospective Cohort Studies With Control Groups } \\
\hline $\begin{array}{l}\text { Shibolet et } \\
\text { al. }{ }^{7}{ }^{7}\end{array}$ & Various & Israel & $\begin{array}{l}1-60 \mathrm{~d} \text { before chemotherapy } \\
0.5-24 \text { mo after completion } \\
\text { of chemotherapy }\end{array}$ & $\begin{array}{l}0.0 \%(0 / 9) \text { vs. } \\
40.0 \%(2 / 5)\end{array}$ & Dose: $150 \mathrm{mg}$ \\
\hline $\begin{array}{l}\text { Idilman } \\
\text { et al. } .^{98}\end{array}$ & Hematologic & Turkey & $\begin{array}{l}\text { Start of chemotherapy } \\
12 \text { mo after completion of } \\
\text { chemotherapy }\end{array}$ & $\begin{array}{l}0.0 \%(0 / 8) \text { vs. } \\
50.0 \%(5 / 10)\end{array}$ & \\
\hline \multicolumn{6}{|c|}{ Randomized Controlled Studies } \\
\hline Lau et al. ${ }^{100}$ & Lymphoma & China & $\begin{array}{l}1 \text { wk before chemotherapy } \\
\text { At least } 6 \text { wk after } \\
\text { completion of chemotherapy }\end{array}$ & $\begin{array}{l}0.0 \%(0 / 15) \text { vs. } \\
53.3 \%(8 / 15)\end{array}$ & \\
\hline $\begin{array}{l}\text { Jang et } \\
\text { al. }^{34}\end{array}$ & $\mathrm{HCC}$ & Korea & $\begin{array}{l}\text { Start of chemotherapy } \\
12 \text { mo after completion of } \\
\text { chemotherapy }\end{array}$ & $\begin{array}{l}2.8 \%(1 / 36) \text { vs. } \\
29.7 \%(11 / 37)\end{array}$ & TACE \\
\hline
\end{tabular}

Abbreviations: HBV, hepatitis B virus; HBeAg, hepatitis B e antigen; HCC, hepatocellular carcinoma; TACE, transarterial chemoembolization. 
Table 4 Comparison of Current Guidelines for Hepatitis B Virus Reactivation

\begin{tabular}{|c|c|c|c|c|}
\hline & $\begin{array}{l}\text { United States } \\
\text { (AASLD }{ }^{27} \text { ) }\end{array}$ & $\begin{array}{l}\text { Europe } \\
\left(\mathrm{EASL}^{24}\right)\end{array}$ & $\begin{array}{l}\text { Asian-Pacific } \\
\left.\text { (APASL }{ }^{26}\right)\end{array}$ & $\begin{array}{l}\text { Korea } \\
\left(\mathrm{KASL}^{25}\right)\end{array}$ \\
\hline $\begin{array}{l}\text { Screening } \\
\text { indication }\end{array}$ & $\begin{array}{l}\text { Patients who are at high } \\
\text { risk for HBV infection }\end{array}$ & $\begin{array}{l}\text { All candidates for } \\
\text { chemotherapy }\end{array}$ & $\begin{array}{l}\text { All candidates for } \\
\text { chemotherapy }\end{array}$ & $\begin{array}{l}\text { All candidates for } \\
\text { chemotherapy }\end{array}$ \\
\hline $\begin{array}{l}\text { Screening } \\
\text { parameters }\end{array}$ & $\mathrm{HBsAg}$ and anti-HBc & $\mathrm{HBsAg}$ and anti-HBc & HBsAg & HBsAg \\
\hline $\begin{array}{l}\text { Screening } \\
\text { timing }\end{array}$ & $\begin{array}{l}\text { Before initiation of } \\
\text { chemotherapy }\end{array}$ & $\begin{array}{l}\text { Before initiation of } \\
\text { chemotherapy }\end{array}$ & $\begin{array}{l}\text { Before initiation of } \\
\text { chemotherapy }\end{array}$ & $\begin{array}{l}\text { Before initiation } \\
\text { of chemotherapy }\end{array}$ \\
\hline \multirow[t]{2}{*}{$\begin{array}{l}\text { Indication of } \\
\text { PAT }\end{array}$} & \multirow[t]{2}{*}{ HBV carriers } & $\begin{array}{l}\text { HBsAg(+) regardless of } \\
\text { HBV DNA }\end{array}$ & \multirow[t]{2}{*}{$\mathrm{HBsAg}(+)$} & \multirow[t]{2}{*}{$\mathrm{HBsAg}(+)$} \\
\hline & & $\begin{array}{l}\text { Recipients of anti-HBc- } \\
\text { positive liver graft }\end{array}$ & & \\
\hline $\begin{array}{l}\text { Timing of } \\
\text { starting PAT }\end{array}$ & $\begin{array}{l}\text { With start of } \\
\text { chemotherapy }\end{array}$ & During chemotherapy & $\begin{array}{l}\text { Before the start of } \\
\text { chemotherapy }\end{array}$ & $\begin{array}{l}\text { Before or } \\
\text { with start of } \\
\text { chemotherapy }\end{array}$ \\
\hline \multirow[t]{2}{*}{ Agent for PAT } & $\begin{array}{l}\text { Lamivudine or } \\
\text { telbivudine, if the } \\
\text { anticipated duration of } \\
\text { treatment is short } \\
(<12 \mathrm{mo})\end{array}$ & $\begin{array}{l}\text { Lamivudine for the } \\
\text { HBsAg(+) patients } \\
\text { with low HBV DNA } \\
\text { levels and low risk of } \\
\text { resistance }\end{array}$ & \multirow[t]{2}{*}{$\begin{array}{l}\text { Lamivudine (other } \\
\text { antiviral agents can } \\
\text { also be used) }\end{array}$} & \multirow[t]{2}{*}{ Not specified } \\
\hline & $\begin{array}{l}\text { Entecavir or tenofovir } \\
\text { is preferred if longer } \\
\text { duration of treatment is } \\
\text { anticipated }\end{array}$ & $\begin{array}{l}\text { Entecavir or tenofovir } \\
\text { for the HBsAg(+) } \\
\text { patients with high } \\
\text { HBV DNA level }\end{array}$ & & \\
\hline \multirow[t]{2}{*}{$\begin{array}{l}\text { Duration of } \\
\text { PAT }\end{array}$} & $\begin{array}{l}\text { For } 6 \text { mo after } \\
\text { completion of therapy, } \\
\text { in case of low baseline } \\
\text { HBV DNA }(<2000 \mathrm{IU} / \mathrm{mL})\end{array}$ & $\begin{array}{l}\text { For } 12 \text { mo after } \\
\text { completion of therapy }\end{array}$ & \multirow[t]{3}{*}{$\begin{array}{l}\text { At least } 12 \mathrm{wk} \text { after } \\
\text { completion of therapy }\end{array}$} & \multirow[t]{3}{*}{$\begin{array}{l}\text { For 3-6 mo after } \\
\text { completion of } \\
\text { therapy }\end{array}$} \\
\hline & $\begin{array}{l}\text { Until reaching } \\
\text { treatment end points } \\
\text { of immunocompetent } \\
\text { patients, in case of high } \\
\text { baseline HBV DNA } \\
\text { (> } 2000 \mathrm{IU} / \mathrm{mL} \text { ) }\end{array}$ & & & \\
\hline $\begin{array}{l}\text { Other } \\
\text { comments }\end{array}$ & $\begin{array}{l}\text { Interferon- } \alpha \text { should } \\
\text { be avoided in view } \\
\text { of the bone marrow } \\
\text { suppressive effect }\end{array}$ & $\begin{array}{l}\text { Vaccination against } \\
\text { HBV seronegative } \\
\text { patients is highly } \\
\text { recommended }\end{array}$ & & \\
\hline
\end{tabular}

Abbreviations: AASLD, American Association for the Study of Liver Diseases; Anti-HBc, hepatitis B core antibody; APASL, AsianPacific Association for the Study of the Liver; EASL, European Association for the Study of the Liver; HBsAg, hepatitis B surface antigen; HBV, hepatitis B virus; KASL, Korean Association for the Study of the Liver; PAT, prophylactic antiviral therapy.

6 months after completion of chemotherapy. Table 4 summarizes the current guidelines for HBV reactivation, and Figure 2 is a proposed practical algorithm for the prevention of HBV reactivation.

Lamivudine-resistant HBV variants can be associated with rapid clinical deterioration after transplantation during lamivudine prophylaxis, ${ }^{89,91}$ and raises concerns. To avoid lamivudine resistance, alternative nucleos(t) ides analogues, such as adefovir, tenofovir, entecavir, or telbivudine, are promising for prophylactic use, ${ }^{29}$ although no data are available on adefovir and entecavir as prophylactic treatment for preventing HBV reactivation. However, these agents are widely used in the management of chronic hepatitis B, and the resistance rate of either agent seems to be lower than lamivudine (12\% for adefovir at 3 years, ${ }^{95} 1 \%$ for entecavir for patients with lamivudine-resistance at 1 year, and $9 \%$ at 2 years). ${ }^{96}$ In general, entecavir is preferred because of its high efficacy and low resistance rate. Interferon- $\alpha$ should be avoided in view of the bone marrow suppressive effect and the risk of hepatitis flares. ${ }^{27}$ 


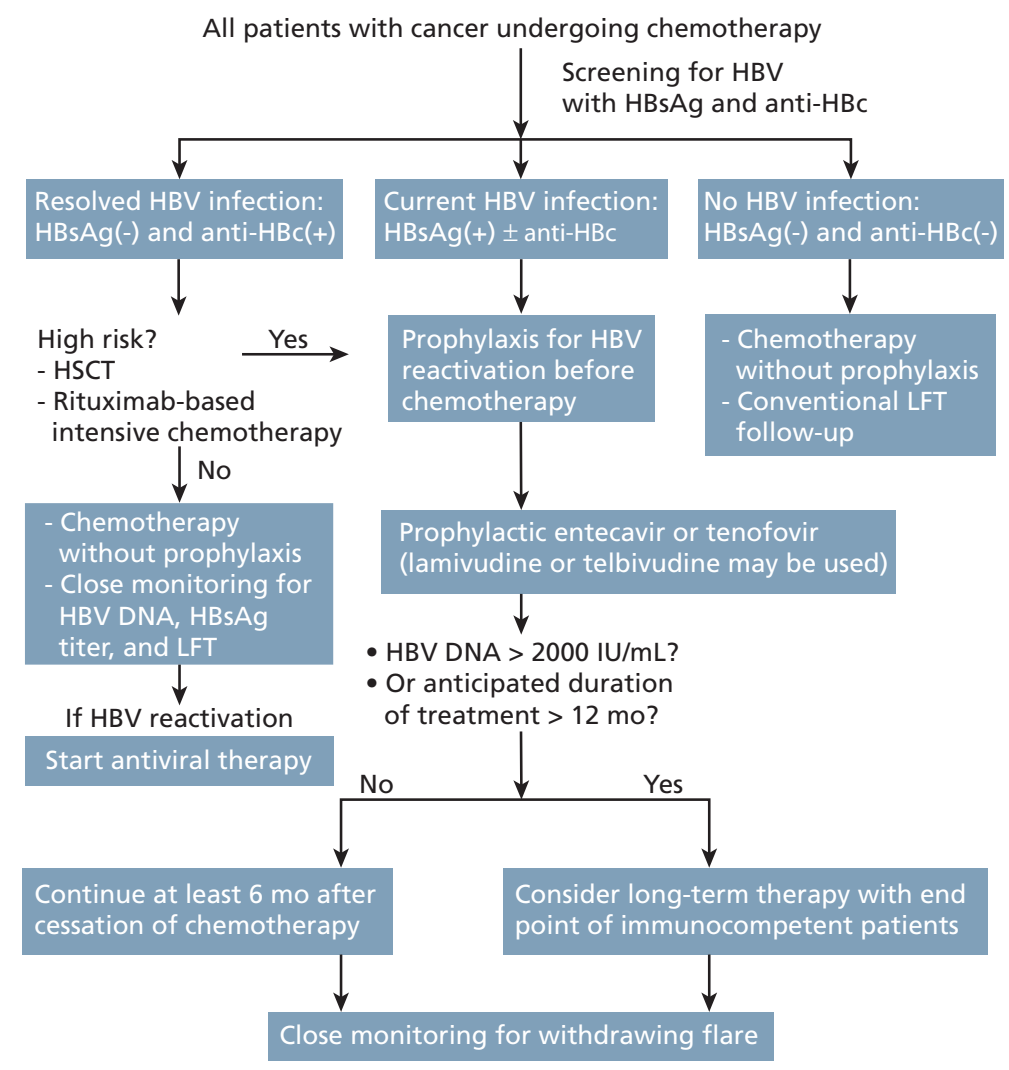

Figure 2 Proposed practical algorithm for the prevention of HBV reactivation in patients with cancer undergoing chemotherapy. Abbreviations: anti-HBc, hepatitis B core antibody; HBsAg, hepatitis B surface antigen; HBV, hepatitis B virus; HSCT, hematopoietic stem cell transplantation; LFT, liver function test.

\section{Unsolved Issues and Future Directions}

To date, most studies have compared the effect of prophylactic antiviral therapy against historical controls. Recommendations are based on limited evidence. A lack of prospective, randomized, controlled trials, uncontrolled observational studies, and different definitions of HBV reactivation have prevented a clear understanding of the role of prophylactic antiviral therapy. Unsolved issues include the optimal antiviral agent with higher potency and less resistance, how to monitor patients for reactivation, and when to stop prophylaxis. Prophylactic strategies in patients with resolved HBV and those treated with molecular targeted chemotherapeutic agents also must be elucidated.

Further randomized controlled studies of prophylaxis versus no prophylaxis in breast cancer or lymphoma do not seem to be necessary. Prospective clinical trials regarding different approaches to prophylaxis are warranted. For example, valuable information can be obtained through prospective clinical trials com- paring the efficacy of lamivudine versus other antiviral agents, such as entecavir, adefovir, and tenofovir, or clinical trials evaluating discontinuation of prophylaxis at 3 or 6 months versus 12 months.

On the research side, a more comprehensive understanding of pathogenesis and identification of viral or host determinants of HBV reactivation enables improved management of HBV reactivation. ${ }^{29}$

\section{Conclusions}

HBV reactivation is a serious clinical problem for HBV carriers undergoing chemotherapy. Screening for HBV is required before chemotherapy, and prophylactic antiviral therapy can reduce not only the incidence of HBV reactivation but also HBV-related morbidity and mortality. Physicians should be aware of this potentially life-threatening but preventable complication, and closely monitor HBV carriers undergoing chemotherapy. 


\section{Acknowledgments}

This study was supported by a grant of the Korea Healthcare Technology R\&D Project, Ministry of Health and Welfare, Republic of Korea (A040151), and by basic science research program through the National Research Foundation of Korea (NRF) funded by the Ministry of Education, Science and Technology (2010-0022299). The authors would like to thank to professor George K. K. Lau for the kind provision of Figure 1, and professor Winnie Yeo for the kind provision of Table 2 .

\section{References}

1. Ganem D, Prince AM. Hepatitis B virus infection-natural history and clinical consequences. N Engl J Med 2004;350:1118-1129.

2. Lavanchy D. Hepatitis B virus epidemiology, disease burden, treatment, and current and emerging prevention and control measures. J Viral Hepat 2004;11:97-107.

3. Kane M. Global programme for control of hepatitis B infection. Vaccine 1995;13(Suppl 1):S47-49.

4. Lee DH, Kim JH, Nam JJ, et al. Epidemiological findings of hepatitis B infection based on 1998 National Health and Nutrition Survey in Korea. J Korean Med Sci 2002;17:457-462.

5. Yeo W, Johnson PJ. Diagnosis, prevention and management of hepatitis $\mathrm{B}$ virus reactivation during anticancer therapy. Hepatology 2006;43:209-220.

6. Loomba R, Rowley A, Wesley R, et al. Systematic review: the effect of preventive lamivudine on hepatitis $B$ reactivation during chemotherapy. Ann Intern Med 2008;148:519-528.

7. Kohrt HE, Ouyang DL, Keeffe EB. Systematic review: lamivudine prophylaxis for chemotherapy-induced reactivation of chronic hepatitis B virus infection. Aliment Pharmacol Ther 2006;24:1003-1016.

8. Kusumoto S, Tanaka Y, Mizokami M, et al. Reactivation of hepatitis B virus following systemic chemotherapy for malignant lymphoma. Int J Hematol 2009;90:13-23.

9. Lok AS, Lai CL, Wu PC, et al. Hepatitis B virus infection in Chinese families in Hong Kong. Am J Epidemiol 1987;126:492-499.

10. Lok AS, Liang RH, Chiu EK, et al. Reactivation of hepatitis B virus replication in patients receiving cytotoxic therapy. Report of a prospective study. Gastroenterology 1991;100:182-188.

11. Jilg W, Hottentrager B, Weinberger K, et al. Prevalence of markers of hepatitis B in the adult German population. J Med Virol 2001;63:96-102.

12. Nakamura Y, Motokura T, Fujita A, et al. Severe hepatitis related to chemotherapy in hepatitis B virus carriers with hematologic malignancies. Survey in Japan, 1987-1991. Cancer 1996;78:2210-2215.

13. Wands JR, Chura CM, Roll FJ, et al. Serial studies of hepatitisassociated antigen and antibody in patients receiving antitumor chemotherapy for myeloproliferative and lymphoproliferative disorders. Gastroenterology 1975;68:105-112.

14. Yeo W, Chan PK, Zhong S, et al. Frequency of hepatitis B virus reactivation in cancer patients undergoing cytotoxic chemotherapy: a prospective study of 626 patients with identification of risk factors. J Med Virol 2000;62:299-307.
15. Yeo W, Chan PK, Hui P, et al. Hepatitis B virus reactivation in breast cancer patients receiving cytotoxic chemotherapy: a prospective study. J Med Virol 2003;70:553-561.

16. Lubel JS, Testro AG, Angus PW. Hepatitis B virus reactivation following immunosuppressive therapy: guidelines for prevention and management. Intern Med J 2007;37:705-712.

17. Lau JY, Bird GL, Gimson AE, et al. Treatment of HBV reactivation after withdrawal of immunosuppression. Lancet 1991;337:802.

18. Vento S, Cainelli F, Longhi MS. Reactivation of replication of hepatitis $B$ and $C$ viruses after immunosuppressive therapy: an unresolved issue. Lancet Oncol 2002;3:333-340.

19. Hoofnagle JH, Dusheiko GM, Schafer DF, et al. Reactivation of chronic hepatitis $B$ virus infection by cancer chemotherapy. Ann Intern Med 1982;96:447-449.

20. Xunrong L, Yan AW, Liang R, et al. Hepatitis B virus (HBV) reactivation after cytotoxic or immunosuppressive therapy-pathogenesis and management. Rev Med Virol 2001;11:287-299.

21. Chou CK, Wang LH, Lin HM, et al. Glucocorticoid stimulates hepatitis B viral gene expression in cultured human hepatoma cells. Hepatology 1992;16:13-18.

22. Tur-Kaspa R, Burk RD, Shaul Y, et al. Hepatitis B virus DNA contains a glucocorticoid-responsive element. Proc Natl Acad Sci U S A 1986;83:1627-1631.

23. Kumagai K, Takagi T, Nakamura S, et al. Hepatitis B virus carriers in the treatment of malignant lymphoma: an epidemiological study in Japan. Ann Oncol 1997;8(Suppl 1):107-109.

24. European Association for the Study of the Liver. EASL clinical practice guidelines. Management of chronic hepatitis B [in French]. Gastroenterol Clin Biol 2009;33:539-554.

25. Lee KS, Kim DJ, Korean Association for the Study of the Liver Guidelines Committee. [Management of chronic hepatitis B]. Korean J Hepatol 2007;13:447-488 [in Korean].

26. Liaw YF, Leung N, Kao JH, et al. Asian-Pacific consensus statement on the management of chronic hepatitis B: a 2008 update. Hepatol Int 2008;2:263-283.

27. Lok AS, McMahon BJ. Chronic hepatitis B: update 2009. Hepatology 2009;50:661-662.

28. Yeo W, Lam KC, Zee B, et al. Hepatitis B reactivation in patients with hepatocellular carcinoma undergoing systemic chemotherapy. Ann Oncol 2004;15:1661-1666.

29. Lau GK. Hepatitis B reactivation after chemotherapy: two decades of clinical research. Hepatol Int 2008;2:152-162.

30. Lau GK, Leung YH, Fong DY, et al. High hepatitis B virus (HBV) DNA viral load as the most important risk factor for HBV reactivation in patients positive for HBV surface antigen undergoing autologous hematopoietic cell transplantation. Blood 2002;99:2324-2330.

31. Jang JW, Choi JY, Bae SH, et al. Transarterial chemo-lipiodolization can reactivate hepatitis $B$ virus replication in patients with hepatocellular carcinoma. J Hepatol 2004;41:427-435.

32. Zhong S, Yeo W, Schroder C, et al. High hepatitis B virus (HBV) DNA viral load is an important risk factor for HBV reactivation in breast cancer patients undergoing cytotoxic chemotherapy. J Viral Hepat 2004;11:55-59.

33. Yeo W, Zee B, Zhong S, et al. Comprehensive analysis of risk factors associating with Hepatitis B virus (HBV) reactivation in cancer patients undergoing cytotoxic chemotherapy. $\mathrm{Br} \mathrm{J}$ Cancer 2004;90:1306-1311.

34. Jang JW, Choi JY, Bae SH, et al. A randomized controlled study of preemptive lamivudine in patients receiving transarterial chemo- 
lipiodolization. Hepatology 2006;43:233-240.

35. Nagamatsu H, Kumashiro R, Itano S, et al. Investigation of associating factors in exacerbation of liver damage after chemotherapy in patients with HBV-related HCC. Hepatol Res 2003;26:293301.

36. Liao CA, Lee CM, Wu HC, et al. Lamivudine for the treatment of hepatitis $B$ virus reactivation following chemotherapy for nonHodgkin's lymphoma. Br J Haematol 2002;116:166-169.

37. Picardi M, Pane F, Quintarelli C, et al. Hepatitis B virus reactivation after fludarabine-based regimens for indolent non-Hodgkin's lymphomas: high prevalence of acquired viral genomic mutations. Haematologica 2003;88:1296-1303.

38. Carman WF, Fagan EA, Hadziyannis S, et al. Association of a precore genomic variant of hepatitis $B$ virus with fulminant hepatitis. Hepatology 1991;14:219-222.

39. Hui CK, Bowden S, Jackson K, et al. Clinical significance of intrahepatic hepatitis B virus covalently closed circular DNA in chronic hepatitis B patients who received cytotoxic chemotherapy. Blood 2005;105:2616-2617.

40. Zoulim F. New insight on hepatitis B virus persistence from the study of intrahepatic viral cccDNA. J Hepatol 2005;42:302-308.

41. Kim MK, Ahn JH, Kim SB, et al. Hepatitis B reactivation during adjuvant anthracycline-based chemotherapy in patients with breast cancer: a single institution's experience. Korean J Intern Med 2007;22:237-243.

42. Yeo W, Ho WM, Hui $P$, et al. Use of lamivudine to prevent hepatitis $\mathrm{B}$ virus reactivation during chemotherapy in breast cancer patients. Breast Cancer Res Treat 2004;88:209-215.

43. Nagamatsu $H$, Itano $S$, Nagaoka $S$, et al. Prophylactic lamivudine administration prevents exacerbation of liver damage in $\mathrm{HBe}$ antigen positive patients with hepatocellular carcinoma undergoing transhepatic arterial infusion chemotherapy. Am J Gastroenterol 2004;99:2369-2375.

44. Yeo W, Hui EP, Chan AT, et al. Prevention of hepatitis B virus reactivation in patients with nasopharyngeal carcinoma with lamivudine. Am J Clin Oncol 2005;28:379-384.

45. Alexopoulos CG, Vaslamatzis M, Hatzidimitriou G. Prevalence of hepatitis B virus marker positivity and evolution of hepatitis B virus profile, during chemotherapy, in patients with solid tumours. Br J Cancer 1999;81:69-74.

46. Niscola P, Del Principe MI, Maurillo L, et al. Fulminant B hepatitis in a surface antigen-negative patient with B-cell chronic lymphocytic leukaemia after rituximab therapy. Leukemia 2005;19:1840-1841.

47. Sarrecchia C, Cappelli A, Aiello P. HBV reactivation with fatal fulminating hepatitis during rituximab treatment in a subject negative for $\mathrm{HBs} \mathrm{Ag}$ and positive for $\mathrm{HBs} \mathrm{Ab}$ and $\mathrm{HBcAb}$. J Infect Chemother 2005;11:189-191.

48. Westhoff TH, Jochimsen F, Schmittel A, et al. Fatal hepatitis B virus reactivation by an escape mutant following rituximab therapy. Blood 2003;102:1930.

49. Dervite I, Hober D, Morel P. Acute hepatitis B in a patient with antibodies to hepatitis B surface antigen who was receiving rituximab. N Engl J Med 2001;344:68-69.

50. Yeo W, Chan TC, Leung NW, et al. Hepatitis B virus reactivation in lymphoma patients with prior resolved hepatitis B undergoing anticancer therapy with or without rituximab. J Clin Oncol 2009;27:605-611.

51. Tsutsumi Y, Tanaka J, Kawamura T, et al. Possible efficacy of lamivudine treatment to prevent hepatitis $B$ virus reactivation due to rituximab therapy in a patient with non-Hodgkin's lymphoma. Ann Hematol 2004;83:58-60.

52. Dai MS, Chao TY, Kao WY, et al. Delayed hepatitis B virus reactivation after cessation of preemptive lamivudine in lymphoma patients treated with rituximab plus CHOP. Ann Hematol 2004;83:769-774.

53. Pei SN, Chen CH, Lee CM, et al. Reactivation of hepatitis $B$ virus following rituximab-based regimens: a serious complication in both HBsAg-positive and HBsAg-negative patients. Ann Hematol 2009;89:255-262.

54. Yamagata M, Murohisa T, Tsuchida K, et al. Fulminant B hepatitis in a surface antigen and hepatitis B DNA-negative patient with diffuse large B-cell lymphoma after CHOP chemotherapy plus rituximab. Leuk Lymphoma 2007;48:431-433.

55. Sera T, Hiasa Y, Michitaka K, et al. Anti-HBs-positive liver failure due to hepatitis $B$ virus reactivation induced by rituximab. Intern Med 2006;45:721-724.

56. Law JK, Ho JK, Hoskins PJ, et al. Fatal reactivation of hepatitis B post-chemotherapy for lymphoma in a hepatitis B surface antigen-negative, hepatitis B core antibody-positive patient: potential implications for future prophylaxis recommendations. Leuk Lymphoma 2005;46:1085-1089.

57. Kim EB, Kim DS, Park SJ, et al. Hepatitis B virus reactivation in a surface antigen-negative and antibody-positive patient after rituximab plus CHOP chemotherapy. Cancer Res Treat 2008;40:3638.

58. Moses SE, Lim ZY, Sudhanva M, et al. Lamivudine prophylaxis and treatment of hepatitis $\mathrm{B}$ virus-exposed recipients receiving reduced intensity conditioning hematopoietic stem cell transplants with alemtuzumab. J Med Virol 2006;78:1560-1563.

59. Iannitto E, Minardi V, Calvaruso G, et al. Hepatitis B virus reactivation and alemtuzumab therapy. Eur J Haematol 2005;74:254258.

60. van der Kolk LE, Baars JW, Prins MH, et al. Rituximab treatment results in impaired secondary humoral immune responsiveness. Blood 2002;100:2257-2259

61. Osterborg A, Dyer MJ, Bunjes D, et al. Phase II multicenter study of human CD52 antibody in previously treated chronic lymphocytic leukemia. European Study Group of CAMPATH1H Treatment in Chronic Lymphocytic Leukemia. J Clin Oncol 1997;15:1567-1574.

62. Lazdina U, Alheim M, Nystrom J, et al. Priming of cytotoxic $T$ cell responses to exogenous hepatitis B virus core antigen is B cell dependent. J Gen Virol 2003;84:139-146.

63. Ikeda K, Shiga Y, Takahashi A, et al. Fatal hepatitis B virus reactivation in a chronic myeloid leukemia patient during imatinib mesylate treatment. Leuk Lymphoma 2006;47:155-157.

64. Kang BW, Lee SJ, Moon JH, et al. Chronic myeloid leukemia patient manifesting fatal hepatitis B virus reactivation during treatment with imatinib rescued by liver transplantation: case report and literature review. Int J Hematol 2009;90:383-387.

65. Lakhani S, Davidson L, Priebat DA, et al. Reactivation of chronic hepatitis B infection related to imatinib mesylate therapy. Hepatol Int 2008;2:498-499.

66. Cheng AL, Kang YK, Chen Z, et al. Efficacy and safety of sorafenib in patients in the Asia-Pacific region with advanced hepatocellular carcinoma: a phase III randomised, double-blind, placebocontrolled trial. Lancet Oncol 2009;10:25-34.

67. Llovet JM, Ricci S, Mazzaferro V, et al. Sorafenib in advanced hepatocellular carcinoma. N Engl J Med 2008;359:378-390. 
68. Shim JH, Park JW, Choi JI, et al. Practical efficacy of sorafenib monotherapy for advanced hepatocellular carcinoma patients in a Hepatitis B virus-endemic area. J Cancer Res Clin Oncol 2009;135:617-625.

69. Kim JW, Lee JO, Han SW, et al. Clinical outcomes of sorafenib treatment in patients with metastatic hepatocellular carcinoma who had been previously treated with fluoropyrimidine plus platinum-based chemotherapy. Am J Clin Oncol, in press.

70. Chen L, Shiah HS, Chen CY, et al. Randomized, phase I, and pharmacokinetic (PK) study of RAD001, an mTOR inhibitor, in patients (pts) with advanced hepatocellular carcinoma (HCC) [abstract]. J Clin Oncol 2009;27(Suppl 1):Abstract 4587.

71. Chen PM, Fan S, Liu CJ, et al. Changing of hepatitis B virus markers in patients with bone marrow transplantation. Transplantation 1990;49:708-713.

72. Seth P, Alrajhi AA, Kagevi I, et al. Hepatitis B virus reactivation with clinical flare in allogeneic stem cell transplants with chronic graft-versus-host disease. Bone Marrow Transplant 2002;30:189194.

73. Dhedin N, Douvin C, Kuentz M, et al. Reverse seroconversion of hepatitis B after allogeneic bone marrow transplantation: a retrospective study of 37 patients with pretransplant anti-HBs and anti-HBc. Transplantation 1998;66:616-619.

74. Onozawa M, Hashino S, Izumiyama K, et al. Progressive disappearance of anti-hepatitis $B$ surface antigen antibody and reverse seroconversion after allogeneic hematopoietic stem cell transplantation in patients with previous hepatitis B virus infection. Transplantation 2005;79:616-619.

75. Knoll A, Boehm S, Hahn J, et al. Reactivation of resolved hepatitis $B$ virus infection after allogeneic haematopoietic stem cell transplantation. Bone Marrow Transplant 2004;33:925-929.

76. Fukushima N, Mizuta T, Tanaka M, et al. Retrospective and prospective studies of hepatitis $\mathrm{B}$ virus reactivation in malignant lymphoma with occult HBV carrier. Ann Oncol 2009;20:2013-2017.

77. Giaccone L, Festuccia M, Marengo A, et al. Hepatitis B virus reactivation and efficacy of prophylaxis with lamivudine in patients undergoing allogeneic stem cell transplantation. Biol Blood Marrow Transplant 2010;16:809-817.

78. Matsue K, Aoki T, Odawara J, et al. High risk of hepatitis B-virus reactivation after hematopoietic cell transplantation in hepatitis B core antibody-positive patients. Eur J Haematol 2009;83:357364.

79. Perez-Grande R, Gutierrez-Zufiaurre N, Munoz-Criado S, et al. Hepatitis $B$ reactivation in a hepatitis $B$ surface antigen-negative patient after allogeneic bone marrow transplant: successful treatment with lamivudine and seroconversion. Diagn Microbiol Infect Dis 2009;64:80-82.

80. Beasley RP, Hwang LY, Lee GC, et al. Prevention of perinatally transmitted hepatitis $B$ virus infections with hepatitis $B$ virus infections with hepatitis B immune globulin and hepatitis B vaccine. Lancet 1983;2:1099-1102.

81. Ahn YO. Strategy for vaccination against hepatitis B in areas with high endemicity: focus on Korea. Gut 1996;38(Suppl 2):S63-66.

82. Katz LH, Fraser A, Gafter-Gvili A, et al. Lamivudine prevents reactivation of hepatitis $B$ and reduces mortality in immunosuppressed patients: systematic review and meta-analysis. J Viral Hepat 2008;15:89-102.

83. Martyak LA, Taqavi E, Saab S. Lamivudine prophylaxis is effective in reducing hepatitis $\mathrm{B}$ reactivation and reactivation-related mortality in chemotherapy patients: a meta-analysis. Liver Int 2008;28:28-38.
84. Lau GK, Piratvisuth T, Luo KX, et al. Peginterferon alfa-2a, lamivudine, and the combination for $\mathrm{HBeAg}$-positive chronic hepatitis B. N Engl J Med 2005;352:2682-2695.

85. Gauthier J, Bourne EJ, Lutz MW, et al. Quantitation of hepatitis $\mathrm{B}$ viremia and emergence of YMDD variants in patients with chronic hepatitis B treated with lamivudine. J Infect Dis 1999;180:1757-1762.

86. Allen MI, Deslauriers M, Andrews CW, et al. Identification and characterization of mutations in hepatitis B virus resistant to lamivudine. Lamivudine Clinical Investigation Group. Hepatology 1998;27:1670-1677.

87. Lok AS, Lai CL, Leung N, et al. Long-term safety of lamivudine treatment in patients with chronic hepatitis B. Gastroenterology 2003;125:1714-1722.

88. Liaw YF, Sung JJ, Chow WC, et al. Lamivudine for patients with chronic hepatitis B and advanced liver disease. N Engl J Med 2004;351:1521-1531.

89. Lee YC, Young KC, Su WC, et al. Emergence of YMDD mutant hepatitis $B$ virus after allogeneic stem cell transplantation from a HBsAG-positive donor during lamivudine prophylaxis. Haematologica 2004;89:ECR09.

90. Pelizzari AM, Motta M, Cariani E, et al. Frequency of hepatitis B virus mutant in asymptomatic hepatitis $B$ virus carriers receiving prophylactic lamivudine during chemotherapy for hematologic malignancies. Hematol J 2004;5:325-328.

91. Chan HL, Chui AK, Lau WY, et al. Outcome of lamivudine resistant hepatitis B virus mutant post-liver transplantation on lamivudine monoprophylaxis. Clin Transplant 2004;18:295-300.

92. Li YH, He YF, Jiang WQ, et al. Lamivudine prophylaxis reduces the incidence and severity of hepatitis in hepatitis B virus carriers who receive chemotherapy for lymphoma. Cancer 2006;106:1320-1325.

93. Kim JS, Hahn JS, Park SY, et al. Long-term outcome after prophylactic lamivudine treatment on hepatitis B virus reactivation in non-Hodgkin's lymphoma. Yonsei Med J 2007;48:78-89.

94. Hui CK, Cheung WW, Au WY, et al. Hepatitis B reactivation after withdrawal of pre-emptive lamivudine in patients with haematological malignancy on completion of cytotoxic chemotherapy. Gut 2005;54:1597-1603.

95. Hadziyannis SJ, Tassopoulos NC, Heathcote EJ, et al. Long-term therapy with adefovir dipivoxil for $\mathrm{HBeAg}$-negative chronic hepatitis B. N Engl J Med 2005;352:2673-2681.

96. Tenney DJ, Rose RE, Baldick CJ, et al. Two-year assessment of entecavir resistance in lamivudine-refractory hepatitis $\mathrm{B}$ virus patients reveals different clinical outcomes depending on the resistance substitutions present. Antimicrob Agents Chemother 2007;51:902-911.

97. Shibolet O, Ilan Y, Gillis S, et al. Lamivudine therapy for prevention of immunosuppressive-induced hepatitis $B$ virus reactivation in hepatitis B surface antigen carriers. Blood 2002;100:391-396.

98. Idilman R, Arat M, Soydan E, et al. Lamivudine prophylaxis for prevention of chemotherapy-induced hepatitis $B$ virus reactivation in hepatitis B virus carriers with malignancies. J Viral Hepat 2004;11:141-147.

99. Lim LL, Wai CT, Lee YM, et al. Prophylactic lamivudine prevents hepatitis B reactivation in chemotherapy patients. Aliment Pharmacol Ther 2002;16:1939-1944.

100. Lau GK, Yiu HH, Fong DY, et al. Early is superior to deferred preemptive lamivudine therapy for hepatitis B patients undergoing chemotherapy. Gastroenterology 2003;125:1742-1749. 
101. Pinto PC, Hu E, Bernstein-Singer M, et al. Acute hepatic injury after the withdrawal of immunosuppressive chemotherapy in patients with hepatitis B. Cancer 1990;65:878-884.

102. Wong GC, Tan P, Goh YT, et al. Exacerbation of hepatitis in hepatitis B carriers following chemotherapy for haematological malignancies. Ann Acad Med Singapore 1996;25:500-503.

103. Lau JY, Lai CL, Lin HJ, et al. Fatal reactivation of chronic hepatitis B virus infection following withdrawal of chemotherapy in lymphoma patients. Q J Med 1989;73:911-917.

104. Galbraith RM, Eddleston AL, Williams R, et al. Fulminant hepatic failure in leukaemia and choriocarcinoma related to withdrawal of cytotoxic drug therapy. Lancet 1975;2:528-530.

105. Ohtsu T, Sai T, Oka M, et al. Activation of hepatitis B virus infection by chemotherapy containing glucocorticoid in hepatitis $\mathrm{B}$ virus carriers with hematologic malignancies. Jpn J Clin Oncol 1991;21:360-365.

106. Dai MS, Wu PF, Shyu RY, et al. Hepatitis B virus reactivation in breast cancer patients undergoing cytotoxic chemotherapy and the role of preemptive lamivudine administration. Liver Int 2004:24:540-546.

107. Yeo W, Mok TS, Tse KK, et al. Phase II study of docetaxel and epirubicin in Chinese patients with metastatic breast cancer. Anticancer Drugs 2002;13:655-662.

108. Mok TS, Zee B, Chan AT, et al. A phase II study of gemcitabine plus oral etoposide in the treatment of patients with advanced nonsmall cell lung carcinoma. Cancer 2000;89:543-550.

109. Cheong K, Li J, Karapetis CS. Gemcitabine and reactivation of hepatitis B. Med Oncol 2003;20:385-388.

110. Grigg AP, Sasadeusz J. Hepatitis B reactivation after thalidomide. Intern Med J 2008;38:301-302.

111. Yeo W, Mok TS, Zee B, et al. A randomized phase III study of doxorubicin versus cisplatin/interferon alpha-2b/doxorubicin/ fluorouracil (PIAF) combination chemotherapy for unresectable hepatocellular carcinoma. J Natl Cancer Inst 2005;97:1532-1538.

112. Persico M, De Marino F, Russo GD, et al. Efficacy of lamivudine to prevent hepatitis reactivation in hepatitis $\mathrm{B}$ virus-infected patients treated for non-Hodgkin lymphoma. Blood 2002;99:724725.

113. Lee GW, Ryu MH, Lee JL, et al. The prophylactic use of lamivudine can maintain dose-intensity of adriamycin in hepatitis-B surface antigen (HBs $\mathrm{Ag}$ )-positive patients with non-Hodgkin's lymphoma who receive cytotoxic chemotherapy. J Korean Med Sci 2003;18:849-854.

114. Leaw SJ, Yen CJ, Huang WT, et al. Preemptive use of interferon or lamivudine for hepatitis $B$ reactivation in patients with aggressive lymphoma receiving chemotherapy. Ann Hematol 2004;83:270275.

115. Ozguroglu M, Bilici A, Turna $H$, et al. Reactivation of hepatitis $B$ virus infection with cytotoxic therapy in non-Hodgkin's lymphoma. Med Oncol 2004;21:67-72.

116. Yeo W, Chan PK, Ho WM, et al. Lamivudine for the prevention of hepatitis $\mathrm{B}$ virus reactivation in hepatitis $\mathrm{B}$ s-antigen seropositive cancer patients undergoing cytotoxic chemotherapy. J Clin Oncol 2004;22:927-934. 